\title{
Features of Indonesian Media Buzzer on Islamic Issues
}

\author{
$1^{\text {st }}$ Rohmani Nur Indah ${ }^{1}, 2^{\text {nd }}$ Halimi Zuhdy ${ }^{1}$ \\ \{indah@bsi.uin-malang.ac.id ${ }^{1}$, halimizuhdy81@gmail.com ${ }^{1}$ \} \\ Universitas Islam Negeri Maulana Malik Ibrahim, Malang, Indonesia ${ }^{1}$
}

\begin{abstract}
This paper explores the features of media buzzer in Indonesia when broadcasting Islamic issues. Media buzzer often becomes the compass of conversational discourse that develops in society that may contain various interests including religious interest. This study employs descriptive qualitative method in examining the media buzzer that placed itself as the 'mouthpiece' of Islam so that it became the focus of analysis. Islamic media buzzer is varied in its efforts to capture the sympathy of netizens. The finding shows the pattern that the posts make use of images or illustrations as visual support that manifests distinct modes of knowledge to reach reader's better understanding. The media buzzers also make use of story to accentuate emotional and surprising element. Another obvious pattern deals with the length of the post. The longer postings are meant to remind readers using supports such as citation, Arabic quotes, prayers and final comment. Whereas, they tend to proscribe readers in shorter postings. By framing the features of the media buzzer conversing on Islamic issues in Indonesia, Islamic netizen needs to operate their higher order thinking skills to identify the distinct concept and point of view offered in the posts.
\end{abstract}

Keywords: critical thinking; Islamic issues; media buzzer; social media

\section{Introduction}

Today media buzzers challenge netizen's critical thinking as their post in several social media. The posts lead to various controversies that demand critical readers to act appropriately, whether to forward, to respond or to ignore the message. The way the users of social media respond the posts of media buzzer is relied on the practice of critical thinking.

Critical thinking, etymologically, is rooted in the ancient Greek lexicon of criticos: tracing decisions and criteria or standards, meaning that the process of developing a search of judgment is based on certain standards [1]. It is also defined as a careful analysis and determination that has implications for an objective decision in figuring out the merits and disadvantages [2]. In the last decade, critical thinking becomes a challenge in the discourse of social media as it requires the reasoning ability, systematically and logically in understanding concepts or beliefs, to take action and solve problems based on the mechanisms of conceptual analysis and argumentation [1].

Critical thinking is a literal human capability that requires deep exploration because of its dynamic and complex nature. The dynamic nature is because of the development according to the process of cognition maturation that begins from the awareness to reveal the results of 
thought in a structured and systematic way to be understood by others. To build that awareness, it requires exposure and practice [3].

Critical thinking is also complex because it involves other factors such as interests, attitudes and personality. This is what needs to be sharpened so as to generate the expertise and interest to learn the field of expertise involving the community and collaboration with those of similar concern [4].

In the context of learning critical thinking, today's critical thinking patterns can be simply observed from the development of expressive abilities [3] to how systemically written expressions can be identified in student papers [Indah, 4]. Reflection on critical thinking is often constrained by writing skills. Therefore, integration between language learning and critical thinking skills is required [5]. Besides, it is also necessary to improve reading skill on various topics because it is related to the improvement of critical thinking skill [6].

In Indonesia the need to integrate critical thinking in education has begun since the implementation of the 2013 curriculum. However, its implementation at the elementary school stage is still constrained on material adequacy. The enrichment material provided still does not meet the communicative standards targeting the development of critical thinking [6]. As for the ideal level, a mapping of critical thinking areas that is appropriate to the context of learners in college [7] is required. Therefore, the study of the development of critical thinking skills in Indonesia still requires further exploration, especially in relation to the context of responding to massive information from social media.

Social media often becomes the compass of conversational discourse that develops in society. It also contains various interests such as political, social and religious interests. Since social media is seen as an effective means of achieving these diverse interests, media buzzers emerge. In this study, the media buzzer that placed itself as the 'mouthpiece' of Islam became the focus of analysis. Islamic media buzzer is varied in its efforts to capture the sympathy of netizens.

Generally, Islamic media buzzers present issues of Islam, nationality issues, issues of diversity and other issues by using verses texts. However, the meaning of the verse's passage is packed in different ways, giving rise to multiple interpretations and understandings. This is because netizens are very heterogeneous in their ability to understand the text they offer.

\section{Literature Review}

\subsection{Critical Thinking and Media}

What is critical thinking? Various definitions are revealed regarding critical thinking, yet it is not a matter of ability but how to control its barriers, that's more important [8]. The mindrelated cognitive process with mental process mechanisms is co-ordinated by brain hemispheres [9]. In this case, it concerns with the language and brain of two schemes: "What to say" and "How to say it". Both can interfere with the process of critical thinking [8].

Critical thinking in Indonesia has emerged primarily since the rise of the reform era in 1998 within the context of freedom of expression [10]. In this case, critical thinking issues are relevant to the $4 \mathrm{R}$ basic competencies that include reading, writing, arithmetic, and reasoning or reading, writing, arithmetic and reasoning [11]. Each of these components is very important in balancing itself with the development of the times. Especially in the information age, the 
ability to reason in filtering information from media buzzer becomes increasingly important to recognize whether an information valid and reliable.

The ability to interpret and identify reason becomes the need of netizen as the target of media buzzer. It takes the skill to make the logical conclusion that underlies an argument regarding the specific issue raised. A logical conclusion or inference can answer whether a strong or weak argument [12]. Netizens or media users are called critical thinkers if they can recognize any logical or proposed mistakes broadcasted by the media buzzer. Media users require the ability to identify problems and connect with their assumptions; explain and narrow the problem; and analyzing, understanding and concluding by applying inductive and deductive logic; and establish the validity and reliability of assumptions, sources of data and information obtained [13]. This ability does not occur immediately, but is obtained through the process of achievement cycle or maturation of the continuum of critical thinking.

Critical thinking stages include basic skills such as asking questions and make predictions, defining problems, testing evidence, analyzing assumptions and recognizing the emergence of information biases. Further netizen as consumers of media buzzer should also be able to avoid emotional reasoning, distancing themselves from simplification or underestimation of certain things, considering different and fixed interpretations tolerate uncertainty [14]. This stage is important for anyone to raise their ability to think critically.

For netizens who are able to think critically, they will not easily fall in the absurd meaning offered by media buzzer. This is because they are able to implement reasoning as follows: monitoring and reviewing and measuring how issues and issues are formulated, how information, data and evidence are represented, and how the quality of reasoning is proposed. As the product is a clear, accurate, accurate, relevant, deep, logical outcome [15].

When faced to Islamic issues broadcasted by media buzzer, ideal netizen can examine the elements of the postings. First, the purpose of the text offered by the media buzzer. Second, the keywords that appear from the text. Third, important information in the form of facts, experiences, and supporting details. Fourth, the emergence of inference through its implied meaning. Fifth, the concept offered that may be different from other concepts. Sixth, the assumption that facilitates the generalization of the information contained in the text. The seventh, point of view, which the reader needs to recognize in order to have a common perspective with the idea arising from the text [16].

\subsection{Indonesian Media Buzzer}

One of the features of the posting of media buzzer is the short message which results in impartial content. The impartiality characterizes the discussion in social media, particularly when conversing controversial issues [17]. More issues resulted on media bias are related to political discourses [18]. However, in Indonesia issues related to religion come first as it is also linked to political interests. The bias in the posting of media buzzer is identifiable from its linguistic cues [19]. Media buzzer also employs effective strategies to catch people's attention and attract their clicks [20].

Despite the growing number of netizen, more people are aware that their literacy skills are being challenged. It is characterized by the decline of journalist's valuation on social media [21]. Netizen today prefer social media to converse non-political issues because of the fear to face online harassment and to make use of social media as a tool for happy interaction [22]. In Indonesia, the non-political discourse taken into account in the dynamic of social media concerns with religion issues as it does not bring the negative consequence such as hatred and risk of harassment. 
When conversing on religion issue, the posting still regards on politeness aspects. Politeness becomes a characteristic in the postings of Islamic media buzzer. When they represent their organization, they use higher politeness, while anonymous postings are lower in politeness [23].

\section{Methods}

This study examined the posting in current Indonesian social media conversing on Islamic issues. The posting taken as the data are those within the criteria of the discourse topic and virality. The topics are relevant to religion issues such as rituals, prayer, good deed, choosing leaders and facing life challenges. While on virality, the data cover the posting which is shared by at least a thousand of social media users.

The data are collected before, during and after the Ramadhan month where the social media take Islamic issues as their topic. Each posting is identified on it features such as number of words, the elements of its content and the implied meaning.

\section{Finding \& Discussion}

From the current postings in several social media accounts such as Instagram, Facebook and Whatsapp, there are Islamic issues spread. The summary of the features of the postings is listed in Table 1.

Table 1. Features of The Postings

\begin{tabular}{|c|c|c|c|}
\hline Topics & Words & Elements & Message \\
\hline $\begin{array}{l}\text { Smoking in } \\
\text { Ramadhan }\end{array}$ & 300 & $\begin{array}{l}\text { Illustration,greetings, } \\
\text { introduction, Arabic } \\
\text { citation, final comment }\end{array}$ & $\begin{array}{l}\text { Reminder } \\
\text { Proscribe }\end{array}$ \\
\hline $\begin{array}{l}\text { Women \& } \\
\text { Dajjal }\end{array}$ & 100 & $\begin{array}{l}\text { Illustration, citation, } \\
\text { prayer }\end{array}$ & Proscribe \\
\hline $\begin{array}{l}\text { KPOP \& } \\
\text { Dajjal }\end{array}$ & 150 & $\begin{array}{l}\text { Illustration, citation, final } \\
\text { comment }\end{array}$ & $\begin{array}{l}\text { Reminder } \\
\text { Proscribe }\end{array}$ \\
\hline $\begin{array}{l}\text { Perfidious } \\
\text { child }\end{array}$ & 320 & $\begin{array}{l}\text { Introduction, prayer, } \\
\text { final comment }\end{array}$ & Reminder \\
\hline $\begin{array}{l}\text { TikTok } \\
\text { phenomenon }\end{array}$ & 190 & $\begin{array}{l}\text { Illustration, Arabic } \\
\text { citation }\end{array}$ & Proscribe \\
\hline $\begin{array}{l}\text { Prayers in } \\
\text { Facebook }\end{array}$ & 350 & $\begin{array}{l}\text { Illustration, introduction, } \\
\text { final comment }\end{array}$ & Reminder \\
\hline $\begin{array}{l}\text { Negative } \\
\text { choices }\end{array}$ & 300 & $\begin{array}{l}\text { Illustration, introduction, } \\
\text { Arabic citation, final } \\
\text { comment }\end{array}$ & Reminder \\
\hline $\begin{array}{l}\text { Curse in short } \\
\text { message }\end{array}$ & 480 & $\begin{array}{l}\text { Introduction, citation, } \\
\text { final comment, } \\
\text { illustration }\end{array}$ & Reminder \\
\hline Sunset demon & 390 & $\begin{array}{l}\text { Introduction, prayer, } \\
\text { illustration, }\end{array}$ & Reminder \\
\hline $\begin{array}{l}\text { Amarcement } \\
\text { of black magic }\end{array}$ & 180 & $\begin{array}{l}\text { Arabic citation, final } \\
\text { comment }\end{array}$ & $\begin{array}{l}\text { Reminder } \\
\text { Proscribe }\end{array}$ \\
\hline Dialog with & 370 & Greeting,citation & Reminder \\
\hline
\end{tabular}




\begin{tabular}{|l|l|l|l|}
\hline demon & & & \\
\hline Islamic leader & $\mathbf{8 0}$ & $\begin{array}{l}\text { Greeting, introduction, } \\
\text { Arabic citation }\end{array}$ & Proscribe \\
\hline
\end{tabular}

The postings on Islamic issues have ranged in length, from 80 to 480 words with the average 265 words. It characterizes the need of social media users that the posting is direct and short. The postings below 200 words cover some elements such as greeting, introduction, citation and final comment. While those above 300 words can only cover minimum elements such as greeting and citation only. This means that the length of the posting is not affected by the completeness of its element.

On the topic of smoking in Ramadhan, the posting starts with the illustration of smoking and its deadly danger. It captures the cover of cigarette stating the warning that smoking kills you. The author greets readers by saying Alhamdulillah expressing gratitude and being thankful to God and the messenger. The opening marks the identity of the author as well as the orientation of the posting that is directed to the Muslim. Then, he introduces the topic on how to optimize good deed during Ramadhan and not doig harmful thing such as smoking. He supports his claim by stating Arabic citation prohibiting smoking. He closes the posting by the final comment to warn readers not to smoke.

The next posting presents the illustration on the symbol of Dajjal or the evil demon and how a girl looks enthusiastic in a style of a Korean pop star representing the symbol of Dajjal. The posting directly states the citation from the hadith to avoid the coming of Dajjal. It is closed with the prayer to prevent Muslim from the appearance of Dajjal. Similar topic on dajjal that is linked to its symbol also starts with an illustration and followed with citation. It ends with the final comment to remind readers about the coming of Dajjal.

On good deed, another posting relates the issue of how child disregard their parents by not enough delivering prayers for parents. The posting describes how the prayer should be done each day. It is clarified in the final comment that the good deed is actually effortless but not seriously done.

Another posting criticizes the TikTok phenomenon that widespread among muslim. The posting starts with an illustration showing how in public sphere people become individualized since they are busy with their gadget. The posting warned muslim not to be busy with the application in their gadget, such as Tiktok which is considered unuseful. To support the claim that proscribe the use of Tiktok, the author inserts Arabic citation on prohibiting useless matters such as music and others.

The next posting discusses how to make use of Facebook wisely, not to share private matters and prayers. The author's claim is supported by some citations from hadith. The final comment highlights the reminder to use Facebook in a better way.

On how to deal with negative choices in deciding something, a posting clarifies a statement that porn video is better than provocative video leading to radicalism. The posting shows the picture of the leader of an Islamic organization citing the essence of the religion to spread peaceful civilization. The author supports the clarification by citing some hadith and ends the posting with reminder to avoid radicalism.

The social media also discuss short message spreading the curse for those who do not forward its message to others. The author claims that it is forbidden to believe the curse. He supports his claim by using citation from hadith. The final comment reminds readers to use short message service for dakwah not for threatening others.

The next posting shares a story on what is happening during sunset where it is commonly believed that demons are coming out looking for a house to visit. The author supports the claim by using some citations to warn children and women to be careful during sunset. The 
posting ends with a final comment offering others to share it and two illustrations showing the appearance of sunset demons.

Another posting covers the amarcement on watching TV show about black magic. It starts with the citations from the Koran and hadith concerning magic rituals and the danger for those believing in magic world. It ends with the final comment offering readers to join the media provider.

The next posting starts with greeting readers and asking them to finish their reading. The author shares the dialog between the Messenger and demon on what is happening when Muslim conducts prayers. It ends with a final comment that asks readers to forward the message to others.

The last posting is on the future leader that should be Islamic leader. The author introduces the topic by relating between the date of governmental election and an ayat in Koran namely Al Maidah 51. The author then uses Arabic citation and the translation of the Koran that diallows Muslims to choose non-Islamic leaders.

From all the postings analyzed in this study, most of texts complete with illustrations that may either introduce the topic or summarize it at the end. The illustration as visual support in social media platform manifests distinct modes of knowledge that may reach a reader's better understanding of the topic being covered [24]. When the image is presented earlier in the posting, it can attract readers to continue reading.

However, media buzzer also offers socio-culture aspect shown by the choice of the illustration. For instance, in the posting concerning sunset demon, the two illustrations given at the end of the text showing obviously the appearance of demons can be the real point to share, not importantly the content of the message. In this case, it is clear that visual information is used maximally by social media buzzer to expose readers into new experience and meaning. The image is structured, processed and presented in such a way to let readers understand and experience the same discourse given [24].

Another characteristic of the posting in Indonesian media buzzer sharing Islamic issue is the use of story to introduce the topic. For instance the story of the author telling about perfidious child, the story of sunset demon and the dialog with the demon. The media buzzer apparently tries to accentuate the emotional and surprising story element in a post [25].

The elements within each posting work altogether to construct a meaning. In this case, the implied meaning refers to the orientation of the text in each topic. In general, the postings have the goal to remind readers or to proscribe them or both. By identifying the message, it can be inferred that the meaning clarifies the pattern and engagement with social media [26]. Media buzzers tend to proscribe readers by using short posts consisting less than 200 words. The longer postings are meant to remind readers using supports such as citation, Arabic quotes, prayers and final comment.

In Indonesian media buzzer conversing Islamic issues, it is identifiable that the purpose is to gain reader's interest in controversial matters related to the current phenomenon. Netizen need to understand such purpose and challenge their critical skills before deciding to spread the posts. It is also noted that most of the posts use citation, either in Arabic or Bahasa Indonesia taken from the Koran, hadith or opinion of Islamic scholar.

However, as the main feature of the post is direct and short, some posts may lack in important information in the form of facts, experiences, and supporting details. In addition, some final comments imply that the media buzzers 'force' readers to forward the message. Critical netizen might be aware of the emergence of inference through such implied meaning.

It is expected that netizen who operate their higher order thinking skills can identify the concept offered in the posts that may be different from other concepts. Further, such netizens 
are also aware of the point of view in the posts in order to have a common perspective with the idea arising from the text [16].

\section{Conclusion}

In this study, Indonesian media buzzers present issues of Islam regarding current phenomenon, good deeds, and socio-cultural aspects by using direct and short texts. However, the meaning of the passage is packed in different ways, through different features. It results in giving rise to multiple interpretations and understandings.

The finding shows the pattern that the posts make use of images or illustrations. They are used as visual support in social media platform that manifests distinct modes of knowledge that may reach a reader's better understanding of the topic being covered. The media buzzers also make use of story as their effort to accentuate emotional and surprising element in the posts. Another obvious pattern deals with the length of the post. The longer postings are meant to remind readers using supports such as citation, Arabic quotes, prayers and final comment. Whereas, the media buzzers tend to proscribe readers in shorter postings.

As the implication of this study, Islamic netizen needs to operate their higher order thinking skills to identify the distinct concept offered in the posts. They are also required to be aware of the point of view reflected in the posts on Islamic issues in order to have a common perspective. Furthermore, the practice of higher order thinking skill as netizen can be a fruitful support for the process of media literacy, particularly in facing some issues like democracy, election and others [27]. The Islamic media buzzer should then compromises its goal to educate Islamic netizen by the three principles of adab-hikmah-'adl namely spreading proper knowledge, producing wisdom and resulting in justice [28].

Acknowledgements. This paper in conjuction with The 1st Annual International Conference on Language, Literature and Media (AICoLLiM 2018) in Malang, East Java.

\section{References}

[1] R. T. Pithers \& R. Soden "Critical thinking in education: a review" Educational Research vol. 42 no. 3 2001, pp. 237-249.

[2] C.R. Taylor. Webster's World University Dictionary. Washington: Webster Publishers Company, Inc. 1965.

[3] R. N. Indah "Discovering student's expertise to augment claim quality in writing class at UIN Maliki Malang" In Widodo, et al. (Eds.) Global Perspective in Literature and Language Teaching, pp.101-107. Malang: Ma Chung University Press. 2010

[4] R. N. Indah "Communicating critical thinking through bilingual reflective writing" In B. Y. Cahyono \& N. Yannuar (Eds.) Englishes for Communication and Interaction in the Classroom and Beyond, Malang: State University of Malang Press. 2012.

[5] R. N. Indah "Critical thinking, writing performance and topic familiarity of Indonesian EFL learners" Journal of Language Teaching and Research vol. 8 no.2 2017, pp. 229-236.

[6] R. N. Indah Critical thinking device and communicativeness of primary school supplementary materials. Unpublished Research Report. Faculty of Humanities UIN Maulana Malik Ibrahim Malang. 2017

[7] R. N Indah \& A. W. Kusuma "Fallacies in English department students' claims: a rhetorical analysis of critical thinking" Jurnal Pendidikan Humaniora vol. 3 no. 4 2015, pp. 281-290. 
[8] Cottrell, S. Critical Thinking Skills London: Palgrave MacMillan 2015.

[9] R. N. Indah Gangguan berbahasa: Kajian pengantar. UIN-Maliki Press, Malang 2017.

[10] E. Emilia Teaching Writing: Developing Critical Learners. Bandung; Rizqi Press. 2010.

[11] B. Hayat, B. \& S. Yusuf Benchmark Internasional Mutu Pendidikan. Jakarta: PT Bumi Aksara 2010.

[12] B. Dowden "Fallacies" Internet Encyclopedia of Philosophy. (http://www.iep.utm.edu/fallacy/) 2010

[13] T.D. Hofreiter, M.C. Monroe \& T.V. Stein "Teaching and evaluating critical thinking in an environmental context" Applied Environmental Education \& Communication vol. 6 no.2 2007, pp. 149-157.

[14] C. Wade "Using writing to develop and assess critical thinking" Teaching of Psychology vol. 22 no. 1 1995, pp. 24-28.

[15] J.A Ernst \& M. Monroe "The effects of environment-based education on students' critical thinking skills and disposition toward critical thinking" Environmental Education Research vol. 10 no. 4 2004, pp. 507-522.

[16] R. Paul \& L. Elder International Critical Thinking Test. NY: Foundation for Critical Thinking 2006.

[17] M. B. Zafar, K. P. Gummadi, C. Danescu-Niculescu-Mizil "Message impartiality in social media discussions" Tenth International AAAI Conference on Web and Social Media 2016, pp. 466475

[18] C. Budak, S.Goel and J. M. Rao "Fair and balanced? Quantifying media bias through crowdsourced content analysis"Public Opinion Quarterly vol. 80, Special Issue, 2016, pp. 250-271.

[19] M. Recasens, C. Danescu-Niculescu-Mizil and D. Jurafsky "Linguistic models for analyzing and detecting biased language" Proceedings of the 51st Annual Meeting of the Association for Computational Linguistics, pp. 1650-1659, Sofia, Bulgaria, August 4-9 2013. Association for Computational Linguistics

[20] J. Reis, F. Benevenuto, P. Olmo, R. Prates, H. Kwak and J. An. "Breaking the news: First impressions matter on online news" In Proc. ICWSM 2015.

[21] M. Djerf-Pierre, M Ghersetti and U. Hedman "Appropriating social media: the changing uses of social media among journalists across time" Digital Journalism vol. 4 no. 7 2016, pp. 849-860.

[22] L. M. Kruse, D. R. Norris and J. R. Flinchum "Social media as a public sphere? Politics on social media The Sociological Quarterly vol. 59 no. 1 2018, pp. 62-84.

[23] D. Halpern and J. Gibbs "Social media as a catalyst for online deliberation? Exploting the affordances of Facebook and YouTube for political expression Computers in Human Behavior vol. 29 no. 1 2013, pp 1159-1168.

[24] N. Hochman "The social media image" Big Data \& Society vol. 1 no. 2 https://doi.org/10.1177/2053951714546645, 2014

[25] J. A. Lischka "Logics in social media news making: How social media editors marry the Facebook logic with journalistic standards" Journalism https://doi.org/10.1177/1464884918788472, 2018

[26] S. Lomborg "Meaning" in Social Media Social Media + Society vol. 1 no. 1 https://doi.org/10.1177/2056305115578673, 2015.

[27] N. Nurhayati \& R. Suryadi " in Democratic challenges of Indonesia in the social media era" Diponegoro Law Review vol 2, no 2 2017pp. 349-358

[28] A. Ramli "Reframing Islamic educational concept for social justice" Jurnal Pencerahan vol 10, no 12016 pp.11-20 